\title{
Understanding the Role of Calcium in Functionality of Part Skim Mozzarella Cheese ${ }^{1}$
}

\author{
N. S. Joshi, ${ }^{\star}, \dagger$ K. Muthukumarappan,† and R. I. Dave* \\ *Dairy Science Department, and \\ †Agricultural and Biosystems Engineering Department, \\ South Dakota State University, \\ Brookings, SD 57007-0647
}

\section{ABSTRACT}

The impact of calcium on softening, melting, and flow characteristics of part skim Mozzarella cheese was evaluated. Four cheeses containing different calcium levels (viz. 0.65, 0.48, 0.42, and $0.35 \%$ ) were manufactured by direct acidification using glucono- $\delta$-lactone on four different occasions. Preacidification of milk was done to alter the calcium content of the cheeses. Cheeses were made with uniform composition. Lowering of calcium to 25,35 , and $45 \%$ levels increased the melt by $1.4,2.1$, and 2.6 times, respectively, $1 \mathrm{~d}$ after manufacture. Low calcium cheeses softened and melted at lower time and temperatures. These cheeses flowed faster and to a greater extent. Higher proteolysis at a faster rate was observed in low calcium cheeses. Refrigerated storage up to $30 \mathrm{~d}$ also increased melt area, flow rate, extent of flow, and soluble protein and lowered softening and melting times in all the cheeses. The effect of calcium reduction was more noticeable as compared to the effect of storage on functionality of Mozzarella cheese. Improved softening, melting, and flow properties of low calcium part skim Mozzarella cheese is a clear advantage to cheese manufacturers and end users as they may not have to wait 15 to $20 \mathrm{~d}$ for proteolysis of cheese to obtain desired melt properties.

(Key words: Mozzarella cheese, calcium, functionality, direct acidification)

\section{INTRODUCTION}

Functional and rheological properties of Mozzarella cheese have gained importance in cheese research during the last decade. The aim has been to produce cheeses that comply with the expectations of end users. Requirements of consumers vary. However, by and large, Moz-

Received September 24, 2002.

Accepted November 22, 2002.

Corresponding author: R. Dave; e-mail: Rajiv_Dave@sdstate.edu. ${ }^{1}$ Published with the approval of Director of the South Dakota Agricultural Experiment Station as Publication Number 3336 of the Journal Series. zarella cheese is expected to exhibit good functional properties, particularly meltability.

Meltability is defined as the ease with which cheese flows or spreads upon heating (Muthukumarappan et al., 1999a). Several methods have been proposed to measure meltability of cheese; however, the Schreiber test of Kosikowski and Mistry (1999) is most commonly used. Muthukumarappan et al. (1999b) observed two major problems with the Schreiber test: 1) noncircular cheese spread and 2) scorching of the outer edges of the spread. In a modified Schreiber test Muthukumarappan et al. (1999b) proposed using area of the melted cheese rather than its maximum diameter.

Calcium plays an important role during manufacturing and also in deciding functionality of cheese (McMahon et al., 1993). Calcium helps to form a network structure during coagulation of milk, provides linkages within and among casein micelles (Walstra, 1990) and affects almost all aspects of cheese manufacture (Lucey and Fox, 1993). It is generally accepted that reduced calcium cheese has higher meltability. Caseins are better able to emulsify fat in curd with reduced calcium (McMahon et al., 1993). Such emulsified fat has fewer tendencies to exude and coalesce from the cheese upon melting. This will result in higher melting, a desirable characteristic in Mozzarella cheese. Effects of altering cooking temperature (Yun et al., 1993a), draw pH (Yun et al., 1994), and milling $\mathrm{pH}$ (Yun et al., 1993b) on the functionality of Mozzarella cheese have been studied. Keller et al. (1974) used preacidified milk to study the characteristics of resultant curd. Merrill et al. (1994) observed improvements in melting and stretching of low fat Mozzarella cheese made from preacidified milk but attributed this change to higher moisture content and not to alteration in calcium level of cheese. Metzger et al. (2001) studied the effects of preacidification of milk with citric and acetic acid on functionality of low fat Mozzarella cheese made with starter culture. They reported that hardness and apparent viscosity of the low fat Mozzarella cheese decreased due to preacidification of milk because of the modification of status of the calcium in the cheese. Recently, Guinee et al. (2002) 
and Feeney et al. (2002) reported that reduced calcium Mozzarella cheeses had increased level of proteolysis and improved functional properties such as stretchability, flowability, meltability, and fluidity. These cheeses also had more swollen and hydrated para-casein matrices. Higher moisture and low protein contents in low calcium cheeses were the factors responsible for improved functionality and increased proteolysis of low calcium cheeses in their study. Role of micellar calcium and soluble calcium on functionality of salted and unsalted part skim Mozzarella cheese was studied recently (Joshi et al., 2002). The authors reported that the calcium bound to casein micelle plays a more important role in governing functional properties than that fortified into milk.

Lowering the level of micellar calcium increased melt and related functional properties, but information on the critical level of calcium removal required to improve meltability of Mozzarella cheese is needed. Also, knowledge regarding changes occurring in softening temperature and time, melting temperature and time, flow rate, and extent of flow in Mozzarella cheeses with different calcium levels would be valuable to better understand the role of calcium in cheese meltability.

The objective of our study was to examine effects of reducing calcium levels by preacidifying milk to various $\mathrm{pH}$ levels on softening, melting, and flow characteristics of part skim Mozzarella cheese of uniform composition. Cheeses were made by direct-acidification using glucono- $\delta$-lactone to reduce interaction effects of starter bacteria in cheese proteolysis during storage. It was expected that the protein breakdown pattern during storage of Mozzarella cheese made without starter culture would be different so proteolysis was also monitored during storage of cheese.

\section{MATERIALS AND METHODS}

\section{Cheese Manufacture}

Skim milk was separated from raw milk procured from the Dairy Research and Training Unit of South Dakota State University, was standardized to $1.8 \%$ fat, batch pasteurized (50-gallon double-walled hot water heated vat processor, Creamery Package, Chicago, IL) at $63^{\circ} \mathrm{C}$ for $30 \mathrm{~min}$, cooled $\left(4^{\circ} \mathrm{C}\right)$, and stored overnight at $4^{\circ} \mathrm{C}$. The next day, part skim Mozzarella cheese was manufactured at the dairy plant of Dairy Science Department of South Dakota State University from the standardized milk using the direct acidification technique (Dave et al., 2001) with few modifications and using four treatments. Fifteen kilograms of milk at $4^{\circ} \mathrm{C}$ was taken in each of four stainless steel vats $(34 \times 22$ $\times 22 \mathrm{~cm}$ ). Vat 1 served as a control. To the other three vats, $15 \mathrm{~g}$ of USP grade citric acid (Columbus Chemical
Ind. Inc., Columbus, WI) followed by a required solution of $10 \%$ (vol/vol) USP grade acetic acid (Columbus Chemical Ind. Inc.) added to bring the $\mathrm{pH}$ of cold $\left(4^{\circ} \mathrm{C}\right)$ milk to $6.2\left(\mathrm{~T}_{1}\right), 5.9\left(\mathrm{~T}_{2}\right)$, and $5.6\left(\mathrm{~T}_{3}\right)$, respectively. Fifteen minutes were allowed for stabilization of $\mathrm{pH}$. Milk was warmed to $35^{\circ} \mathrm{C}$ (for control) and $32^{\circ} \mathrm{C}$ (for $\mathrm{T}_{1}, \mathrm{~T}_{2}$, and $\mathrm{T}_{3}$ ). The lower temperature of curd setting was used in preacidified milk $\left(\mathrm{T}_{1}\right.$ to $\left.\mathrm{T}_{3}\right)$ to allow smooth coagulation. Diluted (1:20 in distilled water) double-strength chymosin (Chymax, Chr. Hansen Inc., Milwaukee, WI) was added $(0.1 \mathrm{ml} / \mathrm{kg}$ of milk) to each vat and the curd was cut, allowed to heal for 10 to $15 \mathrm{~min}$, and then stirred gently to facilitate syneresis. When a sufficient amount of whey was generated, $50 \%$ of whey (based on original milk volume) was drained. Sixty, 50, 40, and $30 \mathrm{~g}$ of glucono- $\delta$-lactone (Sigma Chemical Co., St. Louis, MO) were added to control, $\mathrm{T}_{1}, \mathrm{~T}_{2}$, and $\mathrm{T}_{3}$ vats, respectively, to achieve further lowering of $\mathrm{pH}$ in the curd-whey mixture. The curd-whey mixture was gently stirred and its temperature was gradually raised to $44^{\circ} \mathrm{C}$ over $20 \mathrm{~min}$. Again $25 \%$ of whey was removed and glucono- $\delta$-lactone was added until the $\mathrm{pH}$ of the curd dropped to 5.1. The amount of glucono- $\delta$-lactone varied from 20 to $40 \mathrm{~g}$, depending on the treatment. Final whey draining was followed by dry salting ( $2 \%$, wt/wt) of the curd. Cooking time-temperatures and final draining of whey from all the curd were adjusted such that uniform moisture was obtained in all cheeses. Curd from control and experimental vats $\left(\mathrm{T}_{1}, \mathrm{~T}_{2}\right.$, and $\left.\mathrm{T}_{3}\right)$ was weighed before salting and allowed to drain for more time if required, so that a similar weight for all curds was achieved. Cheese curd was then hand stretched in $5 \%$ salt brine at $77^{\circ} \mathrm{C}$, filled in small $(20 \times 10 \times 8 \mathrm{~cm})$ wooden molds, and immersed in an ice-water bath for $1 \mathrm{~h}$. The cold cheese blocks were cut into four pieces, individually vacuum packaged using a Spiro Mac vacuum packaging machine (Sogevac, France) in a barrier bag (Cryovac, Duncan, SC), and stored at $4^{\circ} \mathrm{C}$ until analysis.

\section{Chemical Analysis}

All cheese samples were grated using a Mouli single drum rotary grater (Moulinex, France), packed in 50mil poly bags (Fisher Scientific, Pittsburgh, PA), and stored $\left(4^{\circ} \mathrm{C}\right)$ until analysis. Each analysis was done in duplicate and average results were expressed. Moisture was determined gravimetrically using the Mojonnier method (Atherton and Newlander, 1987) and fat by modified Babcock method (Marshall, 1992). To determine protein content, total nitrogen content of the cheese was measured by the Kjeldahl method [(AOAC, 2000); (method number 33.7.02.991.20)] and a factor of 6.38 was used to convert nitrogen content to protein content. Ash content was determined by using a muffle 
furnace [(AOAC, 2000); (method number 33.7.07, 935.42)] and salt by the Volhard method [(AOAC, 2000); (method number 33.7.10, 935.43)]. For calcium determination, cheese samples were dried and ashed, and the residues were dissolved and diluted in acidified aqueous solution. The portion was diluted and analyzed by AAS (Atomic Adsorption Spectroscopy) at $422.7 \mathrm{~nm}$ [(AOAC, 2000); (method number 33.7.08, 991.25)].

Proteolysis in cheeses was monitored on d 1, 7, 15, and 30 by determining the soluble protein content by the Kjeldahl method of extract of grated cheese using Sharpe's solution (Kosikowski and Mistry, 1999).

\section{Meltability}

Meltability of the cheese was measured by a modified Schreiber test on d 1, 7, 15, and 30 (Muthukumarappan et al., 1999b). Cheese samples (28.5 mm diameter and $5 \mathrm{~g}$ weight) in triplicate were placed on the center of $0.95-\mathrm{mm}$ thick aluminum plates $(10 \times 10 \mathrm{~cm})$, which were then immediately transferred to an air convective oven (Gallenkamp Plus Oven, UK) at $90^{\circ} \mathrm{C}$. After $5 \mathrm{~min}$, the plates were cooled at room temperature. Area $\left(\mathrm{mm}^{2}\right)$ of the melted cheese was measured using image-processing software (HL Image++98, Western Vision Software; www.wvision.com).

\section{Melt Profile}

A melt profile was determined according to Muthukumarappan et al. (1999a). All the cheeses were tested in triplicate on d 1, 7, 15, and 30. Each cheese sample (28.5 $\mathrm{mm}$ diameter and $5 \mathrm{~g}$ weight) was individually placed in a programmable, forced convection oven (model 838 F, Fisher Scientific, Pittsburgh, PA) at $72^{\circ} \mathrm{C}$. Simultaneous measurement of decrease in cheese height and increase in cheese temperature over time was made using Lab View software (National Instruments Co., Austin, TX). From the graph of time vs. cheese height and temperature, (Figure 1) three distinct linear deformation parts were obtained. The time and temperature at first and last deformations were identified, respectively, as softening and melting. The softening point of cheese was defined as the temperature at which cheese, when heated, changes from being semisolid to a fairly free flowing fluid. The middle linear deformation part was considered as flow. Flow rate was calculated by measuring decrease in height of the cheese with time. Extent of flow was calculated as the difference in initial and final heights of cheese during melting. The data were interpreted in terms of softening time, melting time, softening temperature, melting temperature, flow rate, and extent of flow of cheese during melting.

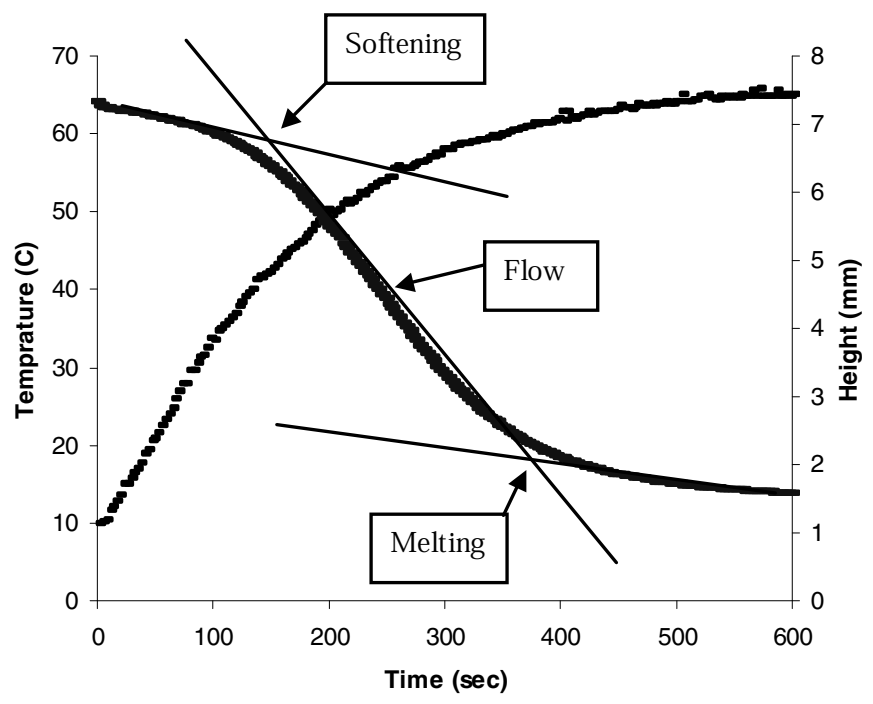

Figure 1. A typical graph representing melt profile (time vs. cheese temperature and height).

\section{Statistical Analysis}

The experiment was replicated four times by making four vats of cheese (control, $\mathrm{T}_{1}, \mathrm{~T}_{2}$, and $\mathrm{T}_{3}$ ) at each time. The data for chemical composition were analyzed using PROC GLM of SAS software (SAS, Version 6.1, SAS Inst. Inc., Cary, NC, 1991) to find significant differences among the treatments. The statistical model employed for composition analysis was:

$$
\mathrm{Y}_{\mathrm{ij}}=\mathrm{T}_{\mathrm{i}}+\mathrm{R}_{\mathrm{j}}+(\mathrm{T} * \mathrm{R})_{\mathrm{ij}}+\varepsilon_{\mathrm{ij}},
$$

where $\mathrm{Y}=$ cheese component, $\mathrm{T}=$ effect of treatment, i.e. lowering of calcium, $(\mathrm{i}=1,2,3,4), \mathrm{R}=$ effect of replication $(\mathrm{j}=1,2,3,4), \mathrm{T}^{*} \mathrm{R}=$ effect of interaction of treatment and replication (error), and $\varepsilon=$ residual variation.

The data of changes in functionality and soluble protein during refrigerated storage were analyzed using split plot design with preacidification of milk to lower calcium content (treatment) as a whole plot and storage period (day) as a subplot. Day and day* day were analyzed as quantitative variables for the subplot factor. The dependent variable as a polynomial function of day was considered in the model. This gives smoothed trends over day and yields equations that can be used for comparing the treatment at specific times or predicting the dependent variable for a treatment at a specific day (Littell et al., 1996). It was observed from the plots that the quadratic equations were adequate for regressions of the dependent variable by day. PROC GLM analyses by SAS (SAS, Version 6.1, SAS Inst. Inc., Cary, NC, 1991) was employed to determine statistical 
parameters. The statistical model employed for data analysis of functionality as well as soluble protein was a mixed model, which was represented by:

$$
\begin{gathered}
\mathrm{Y}_{\mathrm{ijk}}=\mu+\mathrm{T}_{\mathrm{i}}+\alpha_{\mathrm{ij}}+\mathrm{D}_{\mathrm{k}}+(\mathrm{T} * \mathrm{D})_{\mathrm{ik}}+(\mathrm{D} * \mathrm{D})_{\mathrm{k}}+ \\
\left(\mathrm{T}^{*} \mathrm{D} * \mathrm{D}\right)_{\mathrm{ik}}+\varepsilon_{\mathrm{ijk}},
\end{gathered}
$$

where $\mathrm{Y}=$ functional property of cheese, $\mu=$ mean value of a variable, $\mathrm{T}=$ effect of treatment, i.e. lowering of calcium, $(\mathrm{i}=1,2,3,4), \alpha_{\mathrm{ij}}=$ interaction effect of treatment and replication (error-1), $\mathrm{D}=$ effect of storage $(\mathrm{k}$ $=1,2,3,4), \mathrm{T}^{*} \mathrm{D}=$ effect of interaction of treatment and storage period, $\mathrm{D} * \mathrm{D}=$ interaction effect of storage and storage, $\mathrm{T} * \mathrm{D} * \mathrm{D}=$ effect of interaction among treatment, storage and storage, and $\varepsilon=$ residual variation.

\section{RESULTS AND DISCUSSION}

\section{Cheese Manufacturing}

The control milk took longer time (approximately 38 min) compared with rest of the treatments (approximately 15 to $20 \mathrm{~min}$ ), probably because of its high $\mathrm{pH}$ due to no starter addition or preacidification. Keller et al. (1974) observed that calcium loss was affected by $\mathrm{pH}$ at coagulation. Thus, in the control, the calcium loss was expected to be minimal compared with the experimental cheeses.

In the preliminary trials, preacidification of milk was targeted up to $\mathrm{pH} 5.3$; however, the resultant curd was noncohesive and was difficult to handle due to excessive loss of calcium, giving rubbery texture characteristics in the coagulated curd (observation not shown). Keller et al. (1974) also observed similar characteristics of curd made from milk acidified with different acids. They observed that curd from milk preacidified to $\mathrm{pH} 5.4$ with citric acid was soft and became fluid when heated in water at $80^{\circ} \mathrm{C}$ for stretching. Maximum voluminocity of normal casein micelles is around $\mathrm{pH} 5.3$, and swelling of micelles causes increase in their solvation (van Hooydonk et al. 1986). Creamer and Waugh (1966) reported that solvation of $\alpha_{\mathrm{s}}$-casein was inversely related to calcium binding. Thus, excessive removal of calcium might have changed the aggregation and rearrangement characteristics of casein micelles.

During stretching in hot water $\left(77^{\circ} \mathrm{C}\right)$, we also experienced softer and smooth stretch characteristics of experimental cheese curd compared with control cheese (observation not shown), which is in agreement to observations of Metzger et al. (2001). The cheese samples under our experimental conditions reached a temperature of approximately 60 to $65^{\circ} \mathrm{C}$ in various replications. Solvation of cheese protein due to significant influence of anionic species of acid (Keller et al., 1974) and reduction in amount of cross-linking between casein polymers due to calcium lowering (Solorza and Bell, 1995) result into softer cheese. Further, citric acid was the major acidulant to acidify the milk in our study, which among all other acids is reported to yield softer cheese when used to preacidify milk (Keller et al., 1974). Reduction in calcium is also reported to cause lower crosslinking among the protein fibers, which makes cheese softer (van Hooydonk et al., 1986).

\section{Composition}

Moisture, fat, protein, and salt contents of all cheeses (Table 1) were similar $(P>0.05)$. Earlier studies (Merrill et al., 1994; Guinee et al., 2002) attributed improvement in functional properties of low calcium cheeses to their high moisture and low protein contents as a result of preacidification of milk. However, we manufactured cheeses with uniform composition except mineral contents, so that effect of lowering of calcium on functional properties can be studied. The control cheese had maximum $(P<0.05)$ calcium and ash contents followed by $\mathrm{T}_{1}, \mathrm{~T}_{2}$, and $\mathrm{T}_{3}$. Preacidification of milk resulted in solubilization of minerals of milk including calcium (Dalgleish and Law, 1989; van Hooydonk et al., 1986) and thus low calcium and ash contents in the experimental cheeses $(P<0.05)$.

\section{Meltability}

Figure 2 illustrates the images of melted cheese samples on $d 1$. A substantial difference in post melting area was observed and reduction of calcium significantly $(P$ $<0.001$ ) affected the melt area of experimental cheeses (Table 2). The control cheese had minimum melt, and with the reduction in calcium there was a corresponding increase $(P<0.001)$ in the melt area. It was observed that reduction of approximately $25 \%$ of calcium $\left(\mathrm{T}_{1}\right.$ as compared to the control cheese) caused increase in melt area by approximately 1.4 times, and with approximately 35 and $45 \%$ calcium reduction $\left(\mathrm{T}_{2}\right.$ and $\mathrm{T}_{3}$ as compared to control), the increase was approximately 2.1 and 2.6 times, respectively, on $d 1$ (Figures 2 and 3). Melt area of 1-d-old $\mathrm{T}_{2}$ and $\mathrm{T}_{3}$ cheeses were similar $(P>0.05)$. This observation suggested that reduction of calcium beyond $35 \%$ might not be as advantageous with respect to increase in melt area of cheese. The cheese also became excessively soft (more like a fluid) and could be difficult to handle during shredding.

Melting of cheese reflects the ability of cheese particles to flow past one another when heated. For good meltability, a strong interaction between protein and moisture in the cheese structure is required. Lowering 
Table 1. Average $(\mathrm{n}=4)$ composition of part-skim Mozzarella cheese. ${ }^{1}$

\begin{tabular}{lllllll}
\hline & \multicolumn{7}{c}{ Treatment } & & \\
\cline { 2 - 5 } Parameter (\%) & Control & $\mathrm{T}_{1}$ & $\mathrm{~T}_{2}$ & $\mathrm{~T}_{3}$ & SEM & LSD \\
\hline Moisture & 53.62 & 54.52 & 54.58 & 54.00 & 2.66 & 2.51 \\
Fat & 16.75 & 17.50 & 17.50 & 17.50 & 0.81 & 1.39 \\
Protein & 26.14 & 26.22 & 24.96 & 25.48 & 2.37 & 2.37 \\
Ash & $3.03^{\mathrm{a}}$ & $2.90^{\mathrm{ab}}$ & $2.65^{\mathrm{ab}}$ & $2.44^{\mathrm{b}}$ & 0.12 & 0.53 \\
Salt & 1.47 & 1.79 & 1.72 & 1.82 & 0.12 & 0.53 \\
Ca & $0.6475^{\mathrm{a}}$ & $0.4837^{\mathrm{b}}$ & $0.4175^{\mathrm{c}}$ & $0.3550^{\mathrm{c}}$ & 0.002 & 0.0658 \\
\hline
\end{tabular}

a,b,c Means within same row not sharing common superscript are different $(P<0.05)$.

${ }^{1}$ Control $=$ cheese made from milk without preacidification. $\mathrm{T}_{1}=$ cheese made from milk preacidified to $\mathrm{pH}$ 6.2. $\mathrm{T}_{2}=$ cheese made from milk preacidified to $\mathrm{pH}$ 5.9. $\mathrm{T}_{3}=$ cheese made from milk preacidified to $\mathrm{pH}$ 5.6. $\mathrm{SEM}=$ standard error mean. $\mathrm{LSD}=$ least significant difference.

of calcium causes increased interaction between proteins and surrounding water. The protein matrix expands and becomes more hydrated, resulting in increased melting (McMahon and Oberg, 1999). Poor melting of fat-free Mozzarella cheese containing $0.6 \%$ calcium was attributed to incomplete fusion of protein strands (McMahon and Oberg, 1999). For fat-free cheeses, however, dehydration and subsequent skin formation during heating have been reported to be responsible for poor melting. (Rudan and Barbano (1998). We have also observed similar effects in our trials of fatfree cheese (data not shown).

Melt area also increased $(P<0.001)$ with storage in all the cheeses (Figure 3), except for $\mathrm{T}_{2}$ and $\mathrm{T}_{3}$, from $\mathrm{d}$ 15 to 30. During storage of pasta filata type cheeses, the moisture originally present within the fat-serum channels is absorbed into the protein matrix. A well-
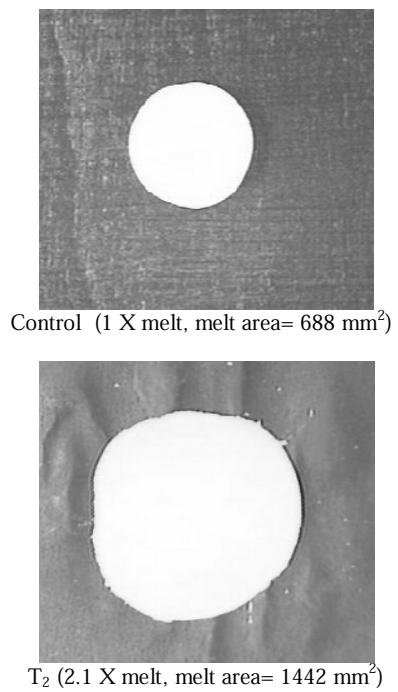
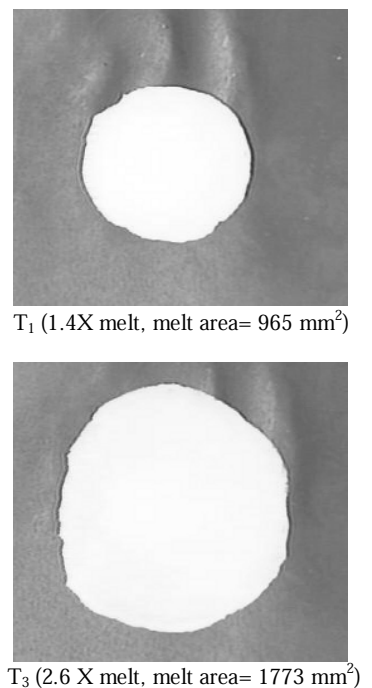

Figure 2. Images of part-skim Mozzarella cheeses after melting on $\mathrm{d} 1$. Control $=$ cheese with $0.65 \%$ calcium, $\mathrm{T}_{1}=$ cheese with $0.48 \%$ calcium, $\mathrm{T}_{2}=$ cheese with $0.42 \%$ calcium, $\mathrm{T}_{3}=$ cheese with $0.35 \%$ calcium. hydrated protein results into good meltability of cheese (McMahon and Oberg, 1999). After $30 \mathrm{~d}$ of refrigerated storage the increase in melt area in control, $\mathrm{T}_{1}, \mathrm{~T}_{2}$, and $\mathrm{T}_{3}$ cheeses was $1.45,1.5,1.13$, and 1.08 times, respectively. Thus, the melt area of control cheese at 30th day of storage was just similar to the melt area of 1-dold $25 \%$ reduced calcium cheese $\left(\mathrm{T}_{1}\right)$. Based on these results, the greater effect of calcium on the functionality of Mozzarella cheese is established compared with the role of proteolysis upon refrigerated storage. For cheese manufacturers it is clearly an advantage because they can obtain increased melt on 1 by altering the calcium content, i.e., without waiting for 15 to $20 \mathrm{~d}$ refrigerated storage for proteolysis to bring the desired changes.

\section{Melt Profile}

Softening. Lowering calcium content had significant effects on softening time and temperature of Mozzarella cheeses (Figure 4). The softening time was influenced

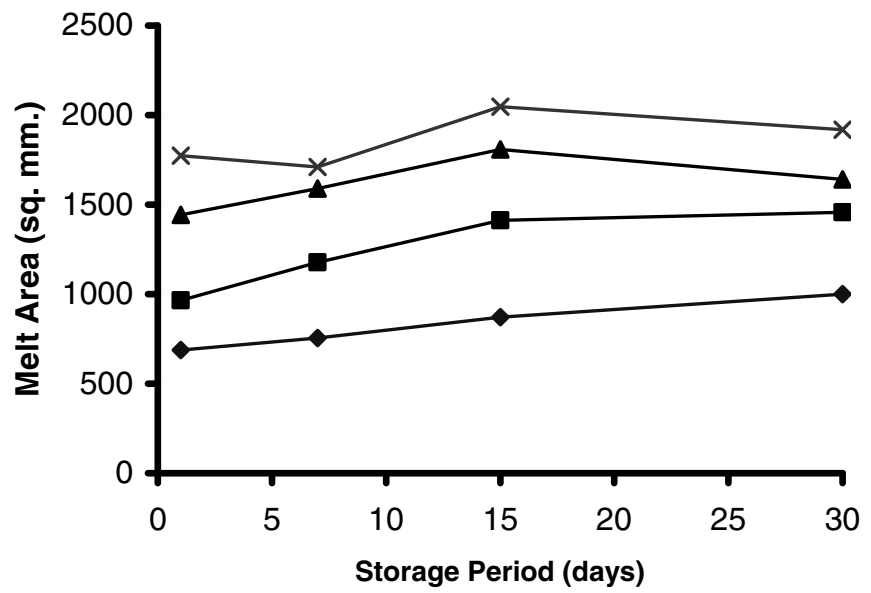

Figure 3. Effect of lowering calcium on melt area of part-skim Mozzarella cheese. $(\bullet)=$ Control, cheese with $0.65 \%$ calcium, $(\square)=$ $\mathrm{T}_{1}$, cheese with $0.48 \%$ calcium, $(\boldsymbol{\Delta})=\mathrm{T}_{2}$, cheese with $0.42 \%$ calcium, $(\mathrm{X})=\mathrm{T}_{3}$, cheese with $0.35 \%$ calcium. 
Table 2. Mean square and probability of properties of part-skim Mozzarella cheese during refrigerated storage.

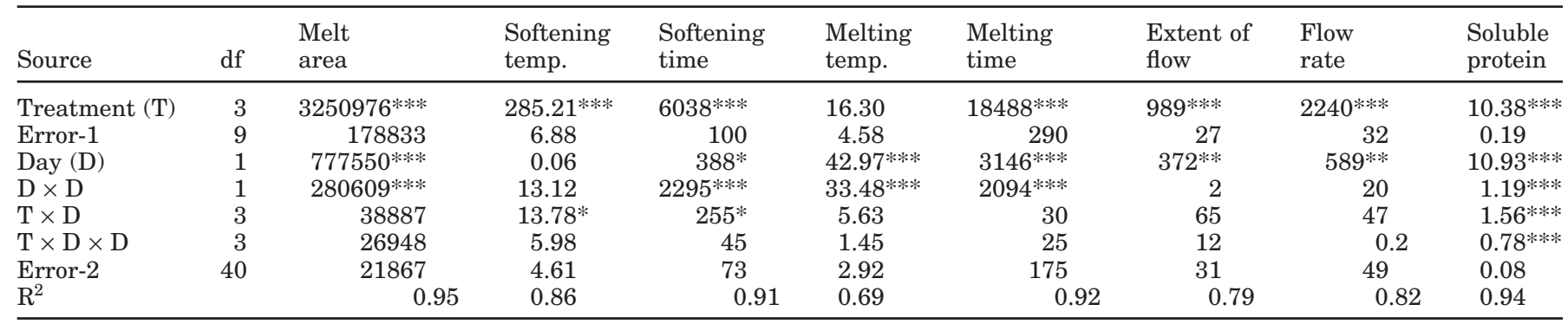

$* P<0.05$.

$* * P<0.01$.

$* * * P<0.001$.

$(P<0.001)$ by treatment as well as the storage period (Table 2). A gradual reduction in time and temperature for cheese softening was observed with reduction in calcium content. This difference was noticeable from day 1 (Figure 4). Reduction in calcium might have brought hydrated milk proteins closer and that probably improved the flow of low calcium cheeses and therefore lowered softening time-temperatures. A slight increase in softening time and then a decline after $15 \mathrm{~d}$ of storage may be associated with the rearrangement of protein matrix and fat-serum channels during refrigerated storage of cheese (McMahon and Oberg, 1999; Tunick et al., 1997). The temperature required to soften the cheese, however, was not affected by the storage period $(P>0.05)$, which suggested that all the cheeses softened at almost same temperature throughout the storage as they did on $\mathrm{d} 1$.

Melting. Effects of alteration of calcium concentration on melting time and temperature of Mozzarella cheeses are shown in Figure 5. The control cheese required significantly longer $(P<0.001)$ time and higher temperature $(P<0.05)$ for melt compared with experimental cheeses. Upon reduction of calcium, incremental reduction in melt time was observed. Reduction of calcium might have brought changes in the structure of the cheese protein network, allowing these cheeses to melt faster and require less time for melt compared with control cheese with higher calcium. Yun et al. (1994) indicated that at higher draw $\mathrm{pH}$ (i.e., higher calcium) the cheese had stronger cross linkages of protein (which maintains structure of cheese) compared with the one at low draining $\mathrm{pH}$. Stronger crosslinks of protein in our control cheese might have maintained its structure during melting; hence, it required higher temperature and more time compared with experimental cheeses.

As expected, a significant $(P<0.001)$ effect of storage on melting time and temperature was also observed (a)

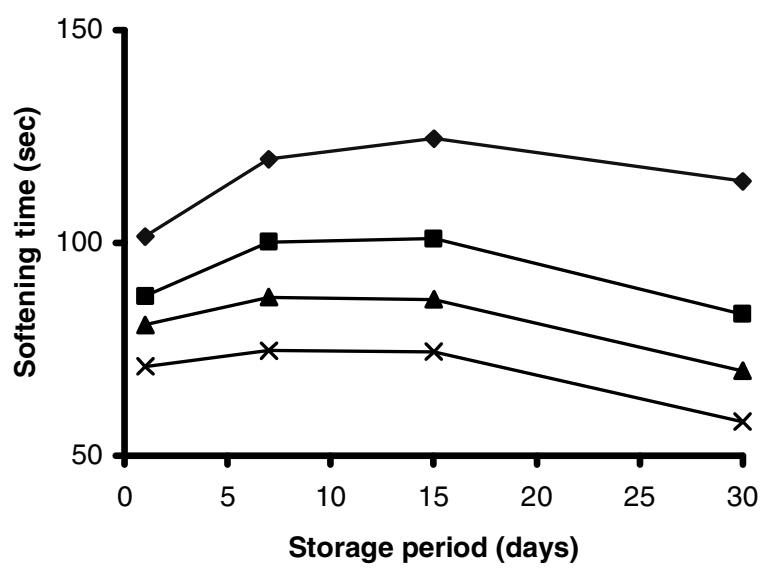

(b)

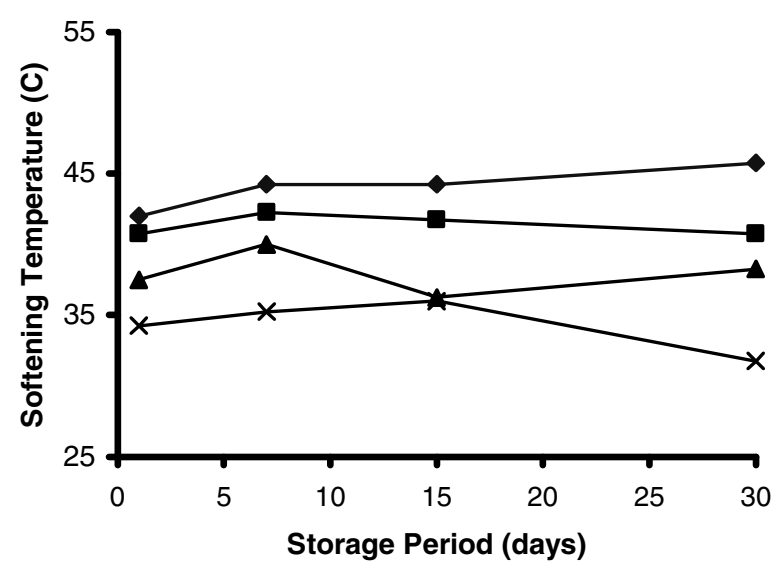

Figure 4. Effect of lowering calcium on softening time (a) and temperature (b) of part-skim Mozzarella cheese. $(\bullet)=$ Control, cheese with $0.65 \%$ calcium, $(\mathbf{\square})=\mathrm{T}_{1}$, cheese with $0.48 \%$ calcium, $(\mathbf{\Delta})=\mathrm{T}_{2}$, cheese with $0.42 \%$ calcium, $(\mathrm{X})=\mathrm{T}_{3}$, cheese with $0.35 \%$ calcium. 
(a)

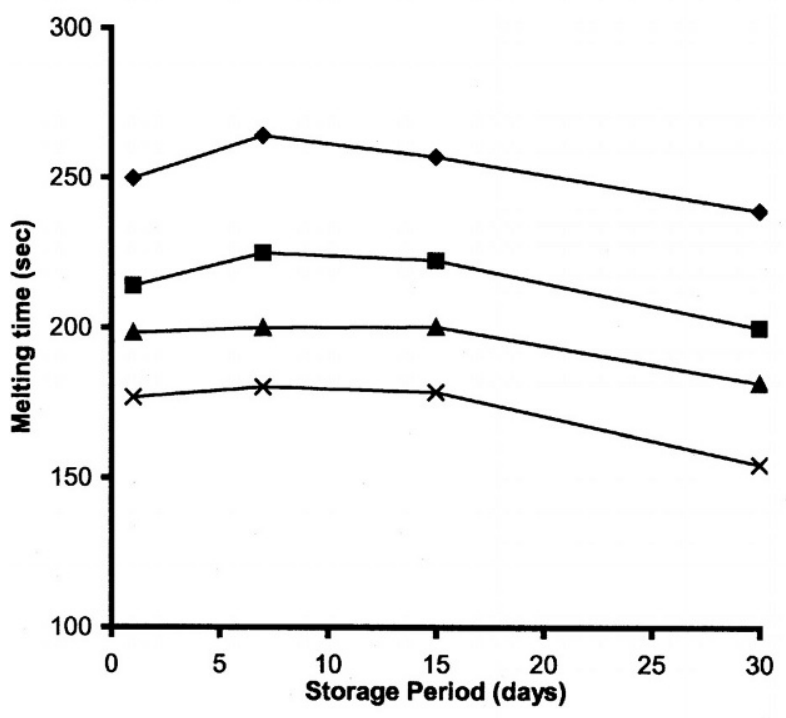

(b)

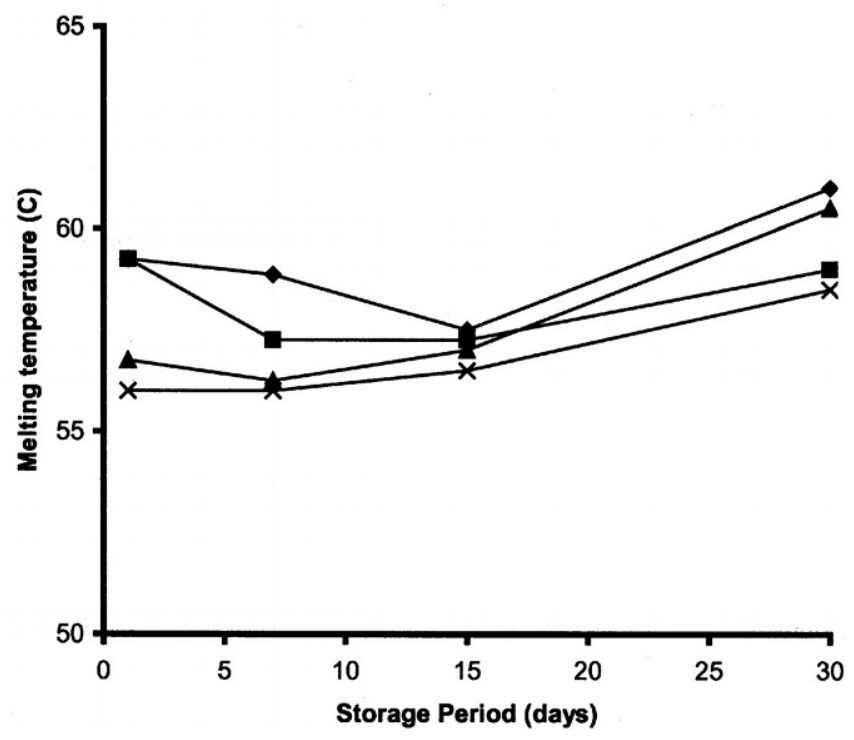

Figure 5. Effect of lowering calcium on melting time (a) and temperature (b) of part-skim Mozzarella cheese. $(\bullet)=$ Control, cheese with $0.65 \%$ calcium, $(\boldsymbol{\square})=\mathrm{T}_{1}$, cheese with $0.48 \%$ calcium, $(\boldsymbol{\Delta})=\mathrm{T}_{2}$, cheese with $0.42 \%$ calcium, $(\mathrm{X})=\mathrm{T}_{3}$, cheese with $0.35 \%$ calcium.

in all the cheeses. As the storage progressed, cheeses melted at lower temperature and required less time to melt; however, after the 15th day of storage, a slight increase in melt temperature was noticeable. When $\alpha_{\mathrm{s}^{-}}$ casein is degraded, the remaining large peptides no longer interact with other caseins, causing the casein submicelles to reorganize into a more porous pattern, which weakens the protein matrix (Tunick et al., 1997) and that increases melting upon storage. Further, the fat globules disperse in the matrix and then coalesce (Tunick et al., 1993) which may contribute to flowing of the protein network and making the cheese more meltable.

Flow. An example of melt behavior (i.e., reduction in height with time during melting) of cheeses is shown in Figure 6. The flow rate as well as the extent of flow of experimental cheeses $\left(\mathrm{T}_{1}\right.$ to $\mathrm{T}_{3}$ ) was significantly higher $(P<0.001)$ than the control cheese (Figure 7$)$. This behavior continued throughout the storage of 30 d. Low concentration of calcium and protein in cheese causes hydration of casein and hence more moisture and more flow in cheese (Guinee et al., 2000). Recently, Guinee et al. (2002) confirmed the higher flowability of low calcium cheese and attributed this behavior to its high moisture and low protein contents. However, in our case, the moisture and protein contents of all the cheeses were similar $(P>0.05)$, and therefore we may attribute such an increase in flow of cheese to lowering of calcium in the experimental cheeses. Apparent viscosity may be correlated with flow properties of cheese.
Metzger et al. (2001) attributed initial low apparent viscosity of low calcium cheese to decreased cross-linking among casein fibers. However, they attributed changes during storage to proteolysis and change in protein $\times$ water interactions.

With refrigerated storage $\left(4^{\circ} \mathrm{C}\right)$, a significant $(P<$ 0.01 ) increase in flow rate and the extent of flow was observed; all cheeses flowed faster and to a greater extent during melting at $\mathrm{d} 30$ compared with $\mathrm{d} 1$. Guinee et al. (2001) attributed increased flowability of low-

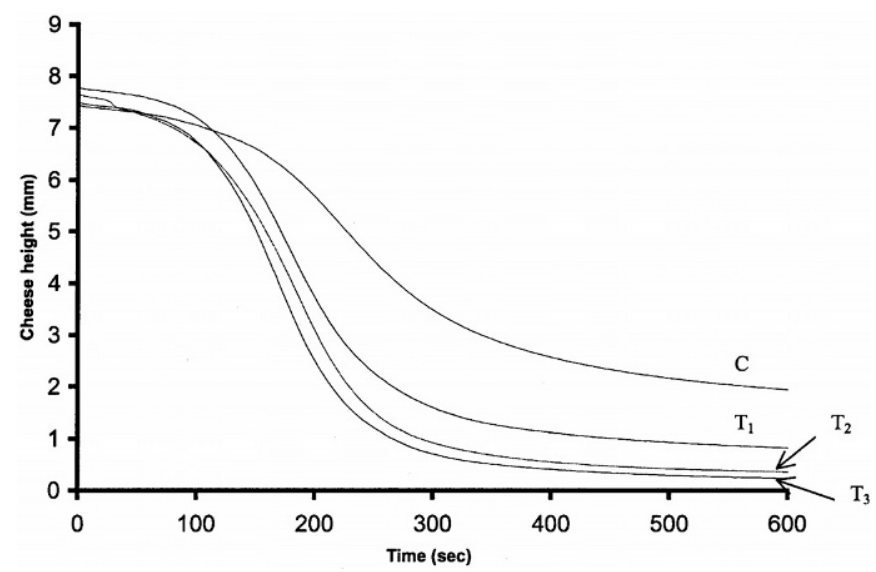

Figure 6. An example of melt behavior of 1-d-old part-skim Mozzarella cheese. Control $=$ cheese with $0.65 \%$ calcium, $\mathrm{T}_{1}=$ cheese with $0.48 \%$ calcium, $\mathrm{T}_{2}=$ cheese with $0.42 \%$ calcium, $\mathrm{T}_{3}=$ cheese with $0.35 \%$ calcium. 
(a)
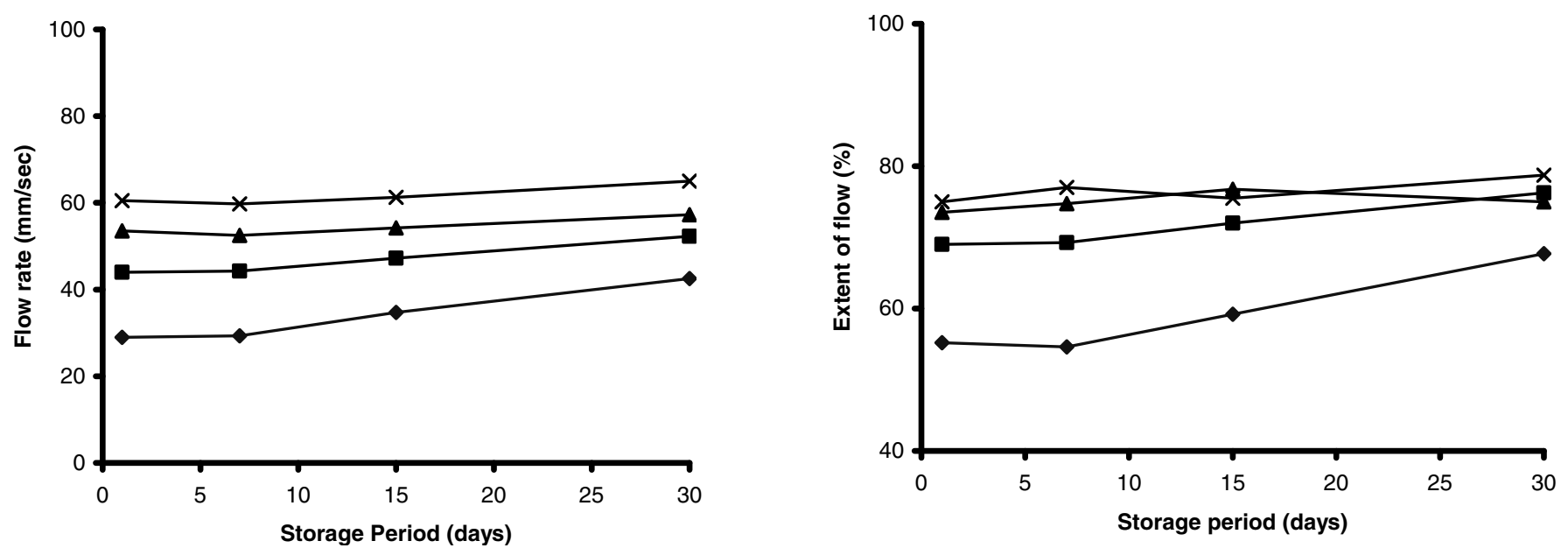

Figure 7. Effect of lowering calcium on flow rate (a) and extent of flow (b) of part-skim Mozzarella cheese. $(\bullet)=$ Control, cheese with $0.65 \%$ calcium, $(\boldsymbol{\square})=\mathrm{T}_{1}$, cheese with $0.48 \%$ calcium, $(\boldsymbol{\Delta})=\mathrm{T}_{2}$, cheese with $0.42 \%$ calcium, $(\mathrm{X})=\mathrm{T}_{3}$, cheese with $0.35 \%$ calcium.

moisture Mozzarella cheese to proteolysis and hydration of para-casein matrix during storage. The caseincasein interaction weakens during storage, thereby increasing the level of displacement of the molten cheese.

\section{Proteolysis}

During storage, a significant increase $(P<0.001)$ in soluble protein in all the cheeses was observed (Figure 8). Lowering of calcium increased $(P<0.001)$ soluble protein content in the experimental cheeses. The effect was noticeable on $\mathrm{d} 1$ in $\mathrm{T}_{3}$ with the lowest amount of

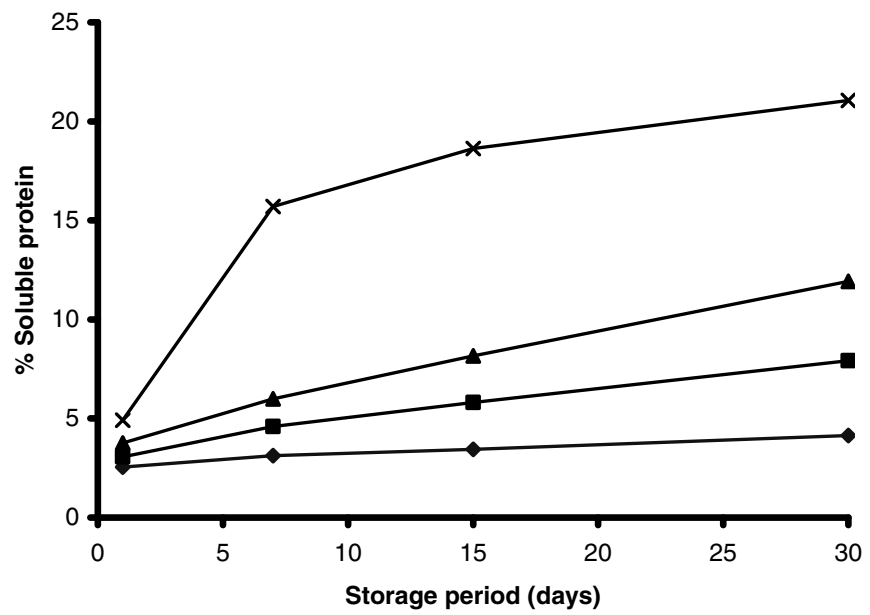

Figure 8. Effect of lowering calcium on soluble protein of part skim Mozzarella cheese. $(\bullet)=$ Control, cheese with $0.65 \%$ calcium, $(\mathbf{\square})=\mathrm{T}_{1}$, cheese with $0.48 \%$ calcium, $(\mathbf{\Delta})=\mathrm{T}_{2}$, cheese with $0.42 \%$ calcium, $(\mathrm{X})=\mathrm{T}_{3}$, cheese with $0.35 \%$ calcium. calcium. Holmes et al. (1977) reported that when the $\mathrm{pH}$ of milk was 6.6 , the activity of chymosin in whey was 72 and $31 \%$ in curd. At $\mathrm{pH}$ 5.2, the activity in whey dropped to $17 \%$ and that in curd increased to $86 \%$. In our case, the experimental cheeses were made from low $\mathrm{pH}$ milks and, hence, activity of chymosin in these cheeses is expected to be correspondingly higher than in the control, resulting into more protein breakdown. The casein of low calcium curd has increased susceptibility to proteolysis by residual chymosin, while the curd is in contact with whey and also during storage (Fox, 1970). The higher extent of proteolysis $(P<0.01)$ on the first day of cheese-making and also throughout storage in the experimental cheeses may be due to the above reasons. This change in proteolysis may also have contributed to greater melting of the experimental cheeses. Solubilization of micellar calcium phosphate diminishes the interaction between the proteins, which may cause swelling and dissociation of casein in form of submicelles (van Hooydonk et al., 1986). The same authors also observed that within the $\mathrm{pH}$ range of 4.6 to 6.6 , the dissociation of casein from the micelle and solubilization of micellar calcium phosphate was maximum at $\mathrm{pH} 5.6$, which yielded more dissolved protein. The $T_{3}$ cheese in the present study was made from the milk preacidified to $\mathrm{pH}$ 5.6. This may be the reason for the maximum amount of soluble protein content in $\mathrm{T}_{3}$ even on $\mathrm{d} 1$ in the present study.

\section{CONCLUSIONS}

Lowering calcium content by preacidifying milk brought several desirable changes in functional proper- 
ties of part skim Mozzarella cheese. Melt area, flow rate, and extent of flow of cheese increased with lowering its calcium content. Reduction of approximately $35 \%$ calcium almost doubled the melt area of the cheese. However, reduction in calcium beyond $35 \%$ was not greatly beneficial for improving the melt of cheese. Lowering of calcium also caused reduction in time-temperature required for softening and melting of cheese. These changes were observed on $\mathrm{d} 1$ of cheese making, which otherwise may take 15 to $20 \mathrm{~d}$ of refrigerated storage. Increase in melt area, flow rate, and extent of flow and in reduction in softening and melting time of cheeses was also observed upon refrigerated storage up to 30 d. However, lowering of calcium had greater influence on the functional properties compared with refrigerated storage of cheeses. Rate of proteolysis increased with lowering of calcium in the cheeses. These results show a clear advantage for industrial application because lowering of calcium by preacidification may not add much cost to the cheese manufacturers, whereas there will be a substantial saving in energy required during refrigerated storage and for softening and melting cheeses. Savings in wait time at retail parlors by the end users is also an added benefit. Lowering of calcium causes alteration in protein matrix, increases the interaction between protein strands and surrounding water of cheese, and affects properties such as softening, melting, and flow that are related to the melt of cheese.

\section{ACKNOWLEDGMENTS}

This paper is based upon work supported by the NRICGP (Award No: 2001-35503-10813, NRI Competitive Grants Program/USDA). The assistance of Cuirong Ren, Assistant Professor, South Dakota State University in statistical analyses is thankfully acknowledged.

\section{REFERENCES}

Association of Official Analytical Chemists. 2000. Official Methods of Analysis. Vol. II. 17th ed. AOAC, Gaithersburg, MD.

Atherton, H. V., and J. A. Newlander. 1987. Chemistry and Testing of Dairy Products, 1st Indian ed. AVI Publ. Co. Inc., Westport, CT.

Creamer, L. K., and D. F. Waugh. 1966. Calcium binding and precipitate solvation of $\mathrm{Ca}-\mathrm{a}_{\mathrm{s}}$-caseinates. J. Dairy Sci. 49:706.

Dalgleish, D. G., and A. J. R. Law. 1989. pH induced dissociation of bovine casein micelles. II. Mineral solubilization and its relation to casein release. J. Dairy Res. 56:727-735.

Dave, R. I., D. J. McMahon, J. R. Broadbent, and C. J. Oberg. 2001. Reversibility of the temperature dependent opacity of nonfat mozzarella cheese. J. Dairy Sci. 84:2364-2371.

Feeney, E. P., T. P. Guinee, and P. F. Fox. 2002. Effect of $\mathrm{pH}$ and calcium concentration on proteolysis in Mozzarella cheese. J. Dairy Sci. 85:1646-1654.

Fox, P. F. 1970. Influence of aggregation on the susceptibility of casein to proteolysis. J. Dairy Res. 37:173-180.

Guinee, T. P., E. P. Feeney, M. A. E. Auty, and P. F. Fox. 2002. Effect of $\mathrm{pH}$ and calcium concentration on some textural and functional properties of Mozzarella cheese. J. Dairy Sci. 85:1655-1669.
Guinee, T. P., E. P. Feeney, and P. F. Fox. 2001. Effect of ripening temperature on low moisture Mozzarella cheese: 2 . Texture and functionality. Lait 81:475-485.

Guinee, T. P., E. O. Mulholland, C. Mullins, and M. O. Corcoran. 2000. Effect of salting method on the composition, yield and functionality of low moisture Mozzarella cheese. Milchwissenschaft 55:135-138.

Holmes, D. G., J. W. Duersch, and C. A. Ernstrom. 1977. Distribution of milk clotting enzymes between curd and whey and their survival during cheddar cheese making. J. Dairy Sci. 60:862-869.

Joshi, N. S., K. Muthukumarappan, and R. I. Dave. 2002. Role of soluble and colloidal calcium contents on functionality of salted and unsalted part skim Mozzarella cheese. Austr. J. Dairy Technol. 57:203-210.

Keller, B., N. F. Olson, and T. Richardson. 1974. Mineral retention and rheological properties of Mozzarella cheese made by direct acidification. J. Dairy Sci. 57:174- 180.

Kosikowski, F. V., and V. V. Mistry. 1999. Cheese and Fermented Milk Foods Vol. II: Procedures and Analysis. 3rd ed. F. V. Kosikowski, L.L.C., Westport, CT.

Littell, R. C., G. A. Milliken, W. W. Stroup, and R. D. Wolfinger. 1996. SAS system for mixed models. SAS Institute Inc. Cary, NC.

Lucey, J. A., and P. F. Fox. 1993. Importance of calcium and phosphate in cheese manufacture: A review. J. Dairy Sci. 76:17141724.

Marshall, R. T. 1992. Chemical and physical methods. Pages 433529 in Standard Methods for Examination of Dairy Products. 16th ed. Am. Publ. Health Assoc., Inc., Washington, DC.

McMahon, D. J., and C. J. Oberg. 1999. Deconstructing Mozzarella. Dairy Ind. Int. 63:23-26.

McMahon, D. J., C. J. Oberg, and W. McManus. 1993. Functionality of Mozzarella cheese. Austr. J. Dairy Technol. 48:99-104.

Merrill, R. K., C. J. Oberg, and D. J. McMahon. 1994. A method for manufacturing reduced fat Mozzarella cheese. J. Dairy Sci. 77:1783-1789.

Metzger, L. E., D. M. Barbano, P. S. Kindstedt, and M. R. Guo. 2001. Effect of milk preacidification on low fat Mozzarella cheese: II. Chemical and functional properties during storage. J. Dairy Sci. 84:1348-1356.

Muthukumarappan, K., Y. C. Wang, and S. Gunasekaran. 1999a. Estimating softening point of cheeses. J. Dairy Sci. 82:2280-2286.

Muthukumarappan, K., Y. C. Wang, and S. Gunasekaran. 1999b. Modified Schreiber test for evaluation of Mozzarella cheese meltability. J. Dairy Sci. 82:1068-1071.

Rudan, M. A., and D. M. Barbano. 1998. A model of Mozzarella cheese melting and browning during pizza baking. J. Dairy Sci. 81:2312-2319.

Solorza, F. J., and A. E. Bell. 1995. Effect of calcium, fat and total solids on the rheology of a model soft cheese system. J. Soc. Dairy Technol. 48:133-139.

Tunick, M. H., P. H. Cooke, E. L. Malin, P. W. Smith, and V. H. Holsinger. 1997. Reorganization of casein sub micelles in Mozzarella cheese during storage. International Dairy J. 7:149-155.

Tunick, M. H., K. L. Mackey, J. J. Shieh, P. W. Smith, P. H. Cooke, and E. L. Malin. 1993. Rheology and microstructure of low fat Mozzarella cheese. Int. Dairy J. 3:649-662.

van Hooydonk A. C. M., H. G. Hagedoorn, and I. J. Boerrigter. 1986. pH-Induced physico-chemical changes of casein micelles in milk and their effect on renettting. 1. Effect of acidification on physicochemical properties. Neth. Milk Dairy J. 40:281-286.

Walstra, P. 1990. On the stability of casein micelles. J. Dairy Sci. 73:1965-1979.

Yun J. J., Y. L. Hsieh, D. M. Barbano, and P. S. Kindstedt. 1994. Draw $\mathrm{pH}$ and storage affect rheological properties of Mozzarella cheese. J. Food Sci. 59:1302-1304.

Yun, J. J., L. J. Kiely, D. M. Barbano, and P. S. Kindstedt. 1993a. Mozzarella cheese: Impact of cooking temperature on chemical composition, proteolysis, and functional properties. J. Dairy Sci. 76:3664-3673.

Yun, J. J., L. J. Kiely, P. S. Kindstedt, and D. M. Barbano. 1993b. Mozzarella cheese: Impact of milling $\mathrm{pH}$ on functional properties. J. Dairy Sci. 76:3639-3647. 